\title{
Risk Modulation of Oral Pre Cancer and Cancer with Polymorphisms in XPD and XPG Genes in North Indian Population
}

\author{
Kumud Nigam¹, Suresh Kumar Yadav, Fahad M Samadi², Madan LB Bhatt ${ }^{3}$, \\ Shalini Gupta ${ }^{2}$, Somali Sanyal ${ }^{1 *}$
}

\begin{abstract}
Background: Environmental carcinogens cause DNA damages which if not repaired properly, may increase the risk of cancer. The Xerodermapigmentosum group $\mathrm{D}(X P D)$ and group $\mathrm{G}(X P G)$ genes are essential genes for DNA repair and alteration in DNA repair causes cancer. The present study aimed to evaluate the relationship between $X P D$ and XPG polymorphisms and risk of oral pre cancer and cancer. Methods: Present study genotyped 302 samples of oral diseases and 300 controls for XPD (A/C) and XPG $(\mathrm{G} / \mathrm{C})$ polymorphisms with PCR-RFLP method. Results: Our result showed that compared to AA genotype frequency of $\mathrm{AC}$ and $\mathrm{CC}$ genotype for $X P D(\mathrm{~A} / \mathrm{C})$ polymorphism were significantly lower among cases than in control and are associated with decreased risk of oral diseases $(\mathrm{OR}=0.621$ and 0.603 respectively). In contrast with reference to GG genotype the frequency of CC genotype of XPG (G/C) was significantly higher in case than in control population ( $\mathrm{p}$ value $=0.004)$ and found to increase the risk of oral diseases $(\mathrm{OR}=2.077)$. Particularly $\mathrm{C}$ allele for $X P D \mathrm{~A} / \mathrm{C}$ polymorphism was found to be associated with decreased risk of Lichen planus and increased risk of ( $\mathrm{OR}=0.470$ and 1.541 respectively) oral cancer. While $\mathrm{C}$ allele of XPG G/C polymorphism significantly increased the risk of Oral Submucous Fibrosis and Leukoplakia (OR=1.879 and 1.837 respectively) but not of Lichen planus and oral cancer. In combined genotype analysis from the aforesaid polymorphisms presence of $\mathrm{C}$ allele for $X P D(\mathrm{~A} / \mathrm{C})$ polymorphisms were found to decrease the risk of oral diseases. However, the same $\mathrm{C}$ allele was observed to increase the chance of having high stage disease $(\mathrm{OR}=5.71)$ with nodal involvement $(\mathrm{OR}=6.78)$ once the cancer been initiated. Conclusion: This work shows association of $X P D(\mathrm{~A} / \mathrm{C}), X P G(\mathrm{G} / \mathrm{C})$ polymorphisms with the development of pre oral cancer as well as oral cancer and its clinical courses.
\end{abstract}

Keywords: Oral pre cancer and cancer- XPD- XPG- PCR-RFLP- gene polymorphism

Asian Pac J Cancer Prev, 20 (8), 2397-2403

\section{Introduction}

Oral cancer, a form of head and neck cancer is present in the oral cavity. It is very frequent with 30,000 cases diagnose worldwide per year (Feraly et al., 2015). Around 75 percent of oral cancers are caused due to use of tobacco and excessive alcohol consumption. Poor oral hygiene, nutrition, and some chronic infections by fungus, bacteria and virus are among the other causes of oral cancer. In most of the cases oral cancer is preceded by pre malignant lesions such as Oral Submucous Fibrosis (OSMF), Leukoplakia and Lichen planus. OSMF is characterized by progressive development of fibrosis in oral submucosa with $5-10 \%$ of them develop to malignancy (Gupta PC et al., 1992). Leukoplakia appears as white patches while Lichen planus is chronic inflammation to mucous membrane of oral cavity.

Cancer is a complex disease related to environmental factors, genetic susceptibility and gene environment interactions. DNA damage caused by environmental factors, such as consumption of tobacco and alcohol, exposure to UV radiation are important risk factors for oral cancer (Wood et al., 2001). This exposures may results in DNA damages such as formation of DNA adducts and cross-links. Damaged DNA if not restored properly with DNA repair system (Cheng et al., 1998) can causes dis-regulation of cell growth and apoptosis which may lead to development of cancer including oral cancer (Kawakami et al., 2015).

DNA repair mechanism is a complex biological system, including five different pathways namely; nucleotide excision repair (NER), Double -strand break repair,

${ }^{1}$ Amity Institute of Biotechnology, Amity University Uttar Pradesh, Lucknow Campus, ${ }^{2}$ Department of Oral Pathology anf Microbiology, ${ }^{3}$ Department of Radiotherapy, King George's Medical University, Lucknow, Uttar Pradesh, India. *For Correspondence: ssanyal@lko.amity.edu 
Base excision repair, Mismatch repair and Homologus recombination repair (Yang, 2012). Gene mutation in NER pathway can develop to several human diseases, including Xerodermapigmentosum (XP) (Spivak et al., 2015). The XP patients can be classified as 8 complementation groups, XPA through XPG. The XPG gene is located on chromosome 13 and synthesizes a DNA endonuclease of 1,186 amino acids. This enzyme is specific for single strand and cleaves the damaged DNA strand at the 3 'end (O’Donovan et al., 1994). Any alteration in XPG gene can impair its DNA repair efficiency which can further cause genomic instability and carcinogenesis (Cheng et al., 2002). XPG gene harbored SNPs and many of those SNPs have been reported to alter the risk of different cancer including colorectal (Moreno et al., 2006), lung (Shen et al., 2005; Sakoda et al., 2012), gastric (He et al., 2012; Yang et al., 2012) and laryngeal (Abbasi et al., 2009).

Xerodermapigmentosum complementation group D $(X P D)$ is involved in NER pathway through recognition and repair of thymidine dimers. The $X P D$ gene contains 23 exons, encodes the 761-amino acid protein and is present in chromosome $19 \mathrm{q} 13.3$. The XPD protein is a part of transcription factor TFIIH and is involved in different functions including nucleotide excision repair (NER), transcription coupled repair, transcription, cell cycle regulation and apoptosis (Sturgis et al., 2000) and therefore, any sequence variation in XPD gene may lead to repair and transcription defects. Several SNPs been identified in XPD gene, and it is thought that certain XPD polymorphisms may be associated with the development of cancer (Goode et al., 2002).

In this study, we investigated the association between XPD (A/C, rs 13181) and XPG (G/C, rs 17655) polymorphisms with the risk of oral cancer and pre cancer.

\section{Materials and Methods}

\section{Study Subjects}

The study was evaluated on 602 subjects including 302 patients with previously treated and pathologically confirmed oral pre cancer and cancer who were registered at department of Oral Pathology and Microbiology, King George's Medical University and 300 healthy controls. This study was approved by the Institutional Ethics Committee of the King George's Medical University, Lucknow. An informed written consent was obtained from all subjects. Venous blood samples were collected in EDTA tubes and stored at $-80^{\circ} \mathrm{C}$, till DNA extraction. Genomic DNA extraction from blood samples was carried out by salting out method (Suguna et al., 2014).

\section{Genotyping by RFLP}

PCR-RFLP method was employed to determine the genotypes of $X P D \mathrm{~A} / \mathrm{C}$ and $X P G \mathrm{G} / \mathrm{C}$ polymorphisms. PCR primers used for the amplification of $X P D \mathrm{~A} / \mathrm{C}$ and XPG G/C polymorphisms were same as used by Sanyal et al., (2004). PCR reactions were carried out with $10 \mathrm{ng}$ of genomic DNA in $10 \mathrm{ul}$ volume reactions containing $0.3 \mathrm{mM}$ each primer, $0.11 \mathrm{mM}$ each $\mathrm{dNTP}, 20$ mMTris-- $\mathrm{HCl}, 50 \mathrm{mMKCl}, 2.0 \mathrm{mM} \mathrm{MgCl}$, and $0.5 \mathrm{U}$ TaqDNApolymerase (Sigma Aldrich,USA). PCR products were digested with Pst I and Nla III respectively to obtain genotypes for $X P D$ and $X P G$ polymorphisms. The digested PCR products were visualize on a $2 \%$ agarose gel stained with ethidium bromide. The genotype results were regularly checked and compared with known genotypes as controls.

\section{Statistical analysis}

The distributions of genotype were checked for the Hardy-Weinberg equilibrium (HWE) and any deviation from HWE was measured with Pearson chi-square test. Comparison between the genotype and allele frequencies among case and control were assessed by the chi-square test. Odds ratio (OR) was calculated to measure the chances of having diseases with the relative frequency of different genotypes and allele among the cases and controls. Odds ratio and $\mathrm{p}$ values were calculated with Epi-Info programme (http://wwwn.cdc.gov/epiinfo/). $\mathrm{P}$ value $<0.05$ was considered to be significant.

\section{Results}

\section{Demographics of the study population}

The demographic profile including gender, age, habitual risk which may responsible for the development of oral cancer and pre oral cancer along with the tumor's clinical parameters, are shown in Table 1. This study involved 302 oral cancer patient, including 203 (67\%) male and $99(33 \%)$ female. Calculated mean age of subject was 46.67. The mean age of controls [219 (73\%) males and $81(27 \%)$ females] was 38.02. Tobacco, smoking chewing and alcohol consumption have been observed

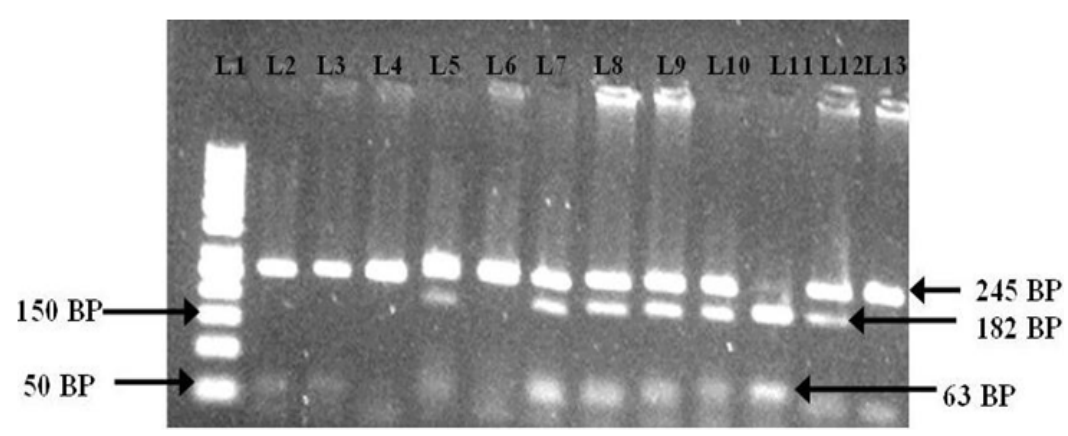

Figure 1. 2.5\% Agarose Gel Analysis of XPD (A/C) Polymorphism. Lane 150 bp Ladder. Lane 2,3,4,5,6,13 AA genotype 245bp.Lane 7,8,9,10,12 AC genotype 245,182, 63bp. Lane 11 CC genotype 182, 63bp. 
Table 1. Demographic Parameters of Patient and Controls and Their Association with Risk of Oral Pre Cancer and Cancer

\begin{tabular}{|c|c|c|c|}
\hline $\begin{array}{l}\text { Demographic } \\
\text { Character }\end{array}$ & $\begin{array}{c}\text { Cases } \\
(\mathrm{n}=302)(\%)\end{array}$ & $\begin{array}{c}\text { Control } \\
(\mathrm{n}=300)(\%)\end{array}$ & P-value \\
\hline \multicolumn{4}{|l|}{ Sex } \\
\hline Male & $203(67)$ & $219(73)$ & Ref \\
\hline Female & $99(33)$ & $81(27)$ & 0.144 \\
\hline \multicolumn{4}{|l|}{ Age distribution } \\
\hline $10-40$ & $89(29)$ & $160(53)$ & Ref \\
\hline $40-90$ & $213(71)$ & $140(47)$ & $<0.0001^{*}$ \\
\hline Mean age & 46.67 & 38.02 & \\
\hline Median age & 47 & 37.5 & \\
\hline \multicolumn{4}{|l|}{ Habitual risk } \\
\hline \multicolumn{4}{|c|}{ Alcohol consumption } \\
\hline Yes & $41(14)$ & $11(04)$ & Ref \\
\hline No & $261(86)$ & $289(96)$ & $<0.0001^{*}$ \\
\hline \multicolumn{4}{|l|}{ Smoking } \\
\hline Yes & $141(46)$ & $78(26)$ & Ref \\
\hline No & $161(54)$ & $222(74)$ & $<0.0001^{*}$ \\
\hline \multicolumn{4}{|l|}{ Tobacco chewing } \\
\hline Yes & $134(44)$ & $73(25)$ & Ref \\
\hline No & $168(56)$ & $227(75)$ & $<0.0001^{*}$ \\
\hline \multicolumn{4}{|c|}{ Type of oral cancer } \\
\hline Leukoplakia & $70(23.33)$ & - & - \\
\hline O.S.M.F & $90(30.00)$ & - & - \\
\hline Lichen planus & $70(23.33)$ & - & - \\
\hline Malignancy & $72(23.33)$ & - & - \\
\hline \multicolumn{3}{|c|}{ TNM staging of oral cancer (Malignancy) } & - \\
\hline Tumor Stage & & - & - \\
\hline I & $8(11)$ & & \\
\hline II & $11(15)$ & & \\
\hline III & $18(25)$ & & \\
\hline IV & $35(49)$ & & \\
\hline \multicolumn{2}{|l|}{ Tumor T Status } & - & - \\
\hline $\mathrm{T} 1+\mathrm{T} 2$ & $10(13)$ & & \\
\hline $\mathrm{T} 3+\mathrm{T} 4$ & $62(87)$ & & \\
\hline \multicolumn{2}{|l|}{ Lymph Node } & - & - \\
\hline No & $25(34)$ & & \\
\hline $\mathrm{N} 1+\mathrm{N} 2$ & $47(66)$ & & \\
\hline \multicolumn{2}{|l|}{ Metastasis } & - & - \\
\hline M0 & $54(75)$ & & \\
\hline M1 & $18(25)$ & & \\
\hline \multicolumn{2}{|c|}{ Cell differentiated grade } & - & - \\
\hline Grade 1 & $31(45)$ & & \\
\hline$>$ Grade 1 & $39(55)$ & & \\
\hline
\end{tabular}

to be significantly associated with the development of oral diseases ( $p$ value $<0.0001$ ). Types of oral diseases included in this study are also mentioned in Table 1, which includes $23.33 \%$ leukoplakia, 30\% OSMF, 23.33\% lichen planus, and $23.33 \%$ malignancy.
Genotypes of XPD and XPG polymorphisms and risk of oral diseases

The different genotype distribution and allele frequency for $X P D \mathrm{~A} / \mathrm{C}, X P G \mathrm{G} / \mathrm{C}$ polymorphisms both in control and cases are represented in Table 2. Both the case and control population were at Hardy-Weinberg equilibrium. With reference to the AA genotype frequency of $\mathrm{AC}$ and $\mathrm{CC}$ genotype for XPD (A/C) polymorphism was significantly low among cases of oral diseases and found to decrease the risk of oral diseases $(\mathrm{OR}=0.621$ and 0.603 respectively). Compared to A allele a significant risk reduction was also observed with $\mathrm{C}$ allele $(\mathrm{OR}=0.758)$. In contrast with reference to GG genotype the frequency of CC genotype of XPG $(\mathrm{G} / \mathrm{C})$ was significantly higher in case than in control population ( $\mathrm{p}$ value $=0.004$ ) and found to increase the risk of oral diseases $(\mathrm{OR}=2.077)$. Increased risk of oral disease was also documented with $\mathrm{C}$ allele of $\mathrm{XPG}(\mathrm{G} / \mathrm{C})$ polymorphism $(\mathrm{OR}=1.425$, $\mathrm{p}$ value $=0.003)$.

Since both $X P D$ and $X P G$ are proteins of NER pathway and functions in collaboration we hypothesized that combined genotypes from $X P D \mathrm{~A} / \mathrm{C}$ and $X P G \mathrm{G} / \mathrm{C}$ polymorphisms might synergistically altered the risk of oral disease. Distribution of different combined genotypes from $X P D(\mathrm{~A} / \mathrm{C})$ and $X P G(\mathrm{G} / \mathrm{C})$ polymorphisms are shown in Table 3. Compared to combined common allele genotype AA/GG the risk of oral disease were found to be significantly reduced with $\mathrm{AA} / \mathrm{CC}, \mathrm{AC} / \mathrm{GC}, \mathrm{AC} / \mathrm{CC}$ and $\mathrm{CC} / \mathrm{CC}$ genotype $(\mathrm{OR}=0.393,0.377,0.237$ and 0.147 respectively).

Genotypes of XPD and XPG polymorphisms and risk of pre oral cancer and oral cancer

The study showed impact of $X P D$ and $X P G$ polymorphisms on the risk of oral disease. In order to investigate the association of them separately with pre oral cancer and oral cancer we further divided the case population into four groups: (i) patients with Oral Submucous Fibrosis (ii) patients with Lichen planus, (iii) patients with Leukoplakia and (ii) patients with oral cancer. The frequency of different genotypes and alleles for $X P D \mathrm{~A} / \mathrm{C}$ and $X P G \mathrm{G} / \mathrm{C}$ polymorphisms among patients of different pre oral cancer diseases and oral cancer are listed in Table 4. Compared to the AA genotype of XPD A/C polymorphism the risk of developing Lichen planus was lower with $\mathrm{AC}$ as well as $\mathrm{CC}$ genotypes $(\mathrm{OR}=$ 0.495 and 0.222 respectively) (Table 4 ). In contrast the $\mathrm{CC}$ genotype and $\mathrm{C}$ allele for the same XPD A/C polymorphism was found to be associated with high risk for oral cancer ( $\mathrm{OR}=2.708$ and 1.541 respectively) (Table 4). However no such association was observed with other pre oral cancer lesions namely OSMF and Leukoplakia. For XPG G/C polymorphism the CC genotype as well as the $\mathrm{C}$ allele significantly increased the risk of OSMF and Leukoplakia but not of Lichen planus and oral cancer (Table 4).

$X P D$ and XPG gene polymorphisms in relation to different clinical parameters of patients with oral cancer

The distribution of different genotypes of XPD A/C and $X P G \mathrm{G} / \mathrm{C}$ polymorphisms among different disease 
Table 2. Distribution of Different Genotypes and Alleles from XPD (A/C) and (G/C) Polymorphisms among Cases of Oral Diseases and Controls

\begin{tabular}{|c|c|c|c|c|c|}
\hline & Cases N (\%) & Controls N (\%) & $\mathrm{p}$ - value & Odds Ratio & $95 \% \mathrm{CI}$ \\
\hline \multicolumn{6}{|c|}{ XPD(A/C) Genotypes } \\
\hline AA & $98(33.00)$ & $70(23.33)$ & Ref & 1 & 1 \\
\hline $\mathrm{AC}$ & $127(43.00)$ & $146(48.66)$ & $0.020 *$ & 0.621 & $0.421-0.916$ \\
\hline $\mathrm{CC}$ & $71(24.00)$ & $84(28.00)$ & $0.032 *$ & 0.603 & $0.388-0.937$ \\
\hline A & $323(54.50)$ & $286(47.66)$ & Ref & 1 & 1 \\
\hline $\mathrm{C}$ & $269(45.50)$ & $314(52.34)$ & $0.020 *$ & 0.758 & $0.604-0.952$ \\
\hline \multicolumn{6}{|c|}{ XPG (G/C) Genotypes } \\
\hline GG & $100(34.12)$ & $122(42.36)$ & Ref & 1 & 1 \\
\hline GC & $130(44.36)$ & $129(44.79)$ & 0.3 & 1.229 & $0.858-1.761$ \\
\hline $\mathrm{CC}$ & $63(21.50)$ & $37(12.84)$ & $0.004 *$ & 2.077 & $1.28-3.37$ \\
\hline G & $330(56.32)$ & $373(64.75)$ & Ref & 1 & 1 \\
\hline $\mathrm{C}$ & $256(43.68)$ & $203(35.25)$ & $0.003 *$ & 1.425 & $1.12-1.80$ \\
\hline
\end{tabular}

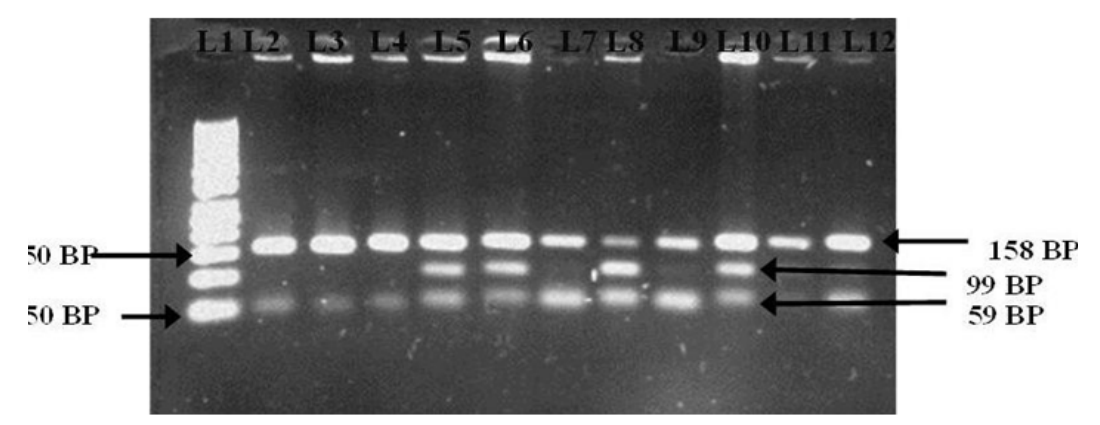

Figure 2. 2.5\% Agarose Gel Analysis of XPG (G/C) Polymorphism. Lane 150 bp Ladder. Lane 2,3,4,7,911,12 GG genotype 158bp. Lane 5,6,10 GC genotype 158,99,59bp. Lane 8 CC genotype 99,59bp.

categories are shown in Table 5. Prevalence of patients with variant allele genotypes $(\mathrm{A} / \mathrm{C}+\mathrm{C} / \mathrm{C})$ for $X P D(\mathrm{~A} / \mathrm{C})$ polymorphism were more $(96 \%)$ among patients who had cancer with lymph node involvement (number of lymph node involved $\mathrm{N} 1+\mathrm{N} 2+\mathrm{N} 3$ ) compared to those who did not (76\%). Similarly compared to patients with AA genotype, patients with variant allele genotypes $(\mathrm{A} / \mathrm{C}+$ $\mathrm{C} / \mathrm{C})$ for $X P D(\mathrm{~A} / \mathrm{C})$ polymorphism had developed high stage tumor at diagnosis $(\mathrm{OR}=5.71$, $\mathrm{p}$ value $=0.049$; Table $5)$. Rest of the clinical parameters of oral cancer did not show any association with $X P D, X P G$ genotypes Table 5 .

\section{Discussion}

Oral cancer is the most commonly found cancer and has been prime health issue in the growing countries including India. Pre oral cancer develops into oral cancer and early treatment of oral lesion could therefore decrease prevalence of oral cancer. This could be achieved by identifying the SNP markers for pre and malignant oral lesion. In this study we investigated the relationship between genotypes of $X P D(\mathrm{~A} / \mathrm{C})$ and $X P G(\mathrm{G} / \mathrm{C})$ polymorphism and risk of oral pre cancer and oral cancer.

Table 3. Distribution of Combined Genotype from XPD (A/C) and XPG (G/C) Polymorphism among the Subject of Oral Diseases and Controls

\begin{tabular}{|c|c|c|c|c|c|}
\hline Combined genotype & Cases N (\%) & Controls N (\%) & $\mathrm{p}$ - value & Odds Ratio & $95 \% \mathrm{CI}$ \\
\hline $\mathrm{AA} / \mathrm{GG}$ & $29(10.03)$ & $14(04.86)$ & Ref & & \\
\hline AA/GC & $40(13.84)$ & $28(09.72)$ & 0.477 & - & - \\
\hline $\mathrm{AA} / \mathrm{CC}$ & $22(07.61)$ & $27(09.37)$ & $0.050^{*}$ & 0.393 & $0.168-0.921$ \\
\hline $\mathrm{AC} / \mathrm{GG}$ & $49(16.95)$ & $17(05.90)$ & 0.581 & - & - \\
\hline $\mathrm{AC} / \mathrm{GC}$ & $50(17.30)$ & $64(22.22)$ & $0.014 *$ & 0.377 & $0.180-0.788$ \\
\hline $\mathrm{AC} / \mathrm{CC}$ & $29(10.03)$ & $59(20.48)$ & $0.0004 *$ & 0.237 & $0.109-0.516$ \\
\hline $\mathrm{CC} / \mathrm{GG}$ & $20(06.92)$ & $06(02.08)$ & 0.57 & & \\
\hline $\mathrm{CC} / \mathrm{GC}$ & $39(13.49)$ & $37(12.84)$ & 0.129 & & \\
\hline $\mathrm{CC} / \mathrm{CC}$ & $11(03.80)$ & $36(12.50)$ & $0.0001 *$ & 0.147 & $0.058-0.373$ \\
\hline
\end{tabular}

*, significant value 
$X P G$ protein serves as structure-specific endonuclease which cleaves different kinds of substrates with ss/ds DNA junction in NER (Evans et al., 1997). The NER complex including XPG removes the lesion from DNA strand. Some study showed that XPG is related to carcinogenesis and prognosis of different types of Cancer (Cheng et al., 2002; Guo et at., 2005; Cheng et al., 2000). Genetic polymorphisms in the XPG gene show significant association with the risk of development of different cancers (Closas et al., 2006; Zienolddiny et al., 2006; Rouissi et al., 2011). In the present study we have observed that the $\mathrm{C}$ allele for XPG G/C polymorphism increased the risk of pre oral cancer namely OSMF, Leukoplakia. To the best of our knowledge our study is first to evaluate the relation of XPG G/C polymorphism with the risk of pre oral cancer. However, we did not find any impact of this XPG polymorphism on oral cancer; neither on its susceptibility nor on its clinical parameters.

$X P D$ contribute to NER by eliminating bulky chemical adducts, certain cross-links, ultraviolet (UV) photo lesions. $X P D$ protein posses a 59-39 DNA helicase activities and it is a single-strand DNA-dependant ATPase which plays an important role in transcription and NER pathway (Lunn, 2000). In the present study the $\mathrm{C}$ allele from $X P D$ $\mathrm{A} / \mathrm{C}$ polymorphism were associated with reduced risk of Lichen planus. Similar protective association of this allele with the development of oral cancer has also been reported previously (Pereiraa et al., 2016). They have also reported that the $\mathrm{C}$ allele of $X P D \mathrm{~A} / \mathrm{C}$ polymorphism was associated with high grade oral squamous cell carcinoma. Similarly, we have also observed that once oral cancer is established the $\mathrm{C}$ allele enhanced the risk of having high stage malignant disease with nodal involvement. Several other cases have reported the link of $X P D \mathrm{~A} / \mathrm{C}$ polymorphism with the development of different cancer in different population indicates its universal role in carcinogenesis (Du et al., 2016; Smolarz et al., 2019; Avci et al., 2018; Zhu et al., 2018).

Since a single polymorphism shows low penetrance we combined the genotypes from studied polymorphism to find any combined effect of them on disease susceptibility. Our results from the present study indicate polymorphisms from $X P D$ and $X P G$ exert synergistic effect on the development of oral diseases. The protective effect of $\mathrm{C}$ allele from $X P D \mathrm{~A} / \mathrm{C}$ polymorphism suppressed the risk enhancing effect of $\mathrm{C}$ allele of XPG G/C polymorphism.

In conclusion, this study shows association of XPD $(\mathrm{A} / \mathrm{C}), \mathrm{XPG}(\mathrm{G} / \mathrm{C})$ polymorphisms with the risk for development of pre oral cancer as well as oral cancer. However, due to small sample size in different disease group our finding are rather suggestive than conclusive and warn larger studies.

\section{Acknowledgments}

We are thankful to Prof J.K Srivastava, Director, Amity institute of Biotechnology, Amity University Uttar Pradesh Lucknow Campus, Lucknow, India. We are also grateful to Dr Sabyasachi Sanyal for helpful comments. 
Table 5. Association of Different Genotypes for XPD (A/C) and XPG (G/C) Polymorphism with Tumor Stage, Tumor T Status, Lymph Node, Metastasis and Grade in Oral Cancer Patients

\begin{tabular}{|c|c|c|c|c|c|}
\hline \multicolumn{6}{|c|}{ XPD (A/C), XPG (G/C) Genotypes/Alleles } \\
\hline & $\begin{array}{l}\mathrm{T} 3+\mathrm{T} 4 \\
\mathrm{~N}(\%)\end{array}$ & $\begin{array}{l}\mathrm{T} 1+\mathrm{T} 2 \\
\mathrm{~N}(\%)\end{array}$ & P-value & Odds Ratio & $95 \% \mathrm{CI}$ \\
\hline \multicolumn{6}{|l|}{ Tumor T Status } \\
\hline \multicolumn{6}{|l|}{$\mathrm{XPD}(\mathrm{A} / \mathrm{C})$} \\
\hline AA & $03(08)$ & $05(15)$ & Reference & Reference & Reference \\
\hline $\mathrm{AC}+\mathrm{CC}$ & $34(92)$ & $28(85)$ & 0.583 & 2.024 & $0.444-9.222$ \\
\hline \multicolumn{6}{|l|}{ XPG $(\mathrm{G} / \mathrm{C})$} \\
\hline GG & $21(58)$ & $12(38)$ & Reference & Reference & Reference \\
\hline $\mathrm{GC}+\mathrm{CC}$ & $15(42)$ & $19(62)$ & 0.174 & 0.451 & $0.169-1.203$ \\
\hline Lymph Node & $\begin{array}{c}\mathrm{N} 1+\mathrm{N} 2+\mathrm{N} 3 \\
\mathrm{~N}(\%)\end{array}$ & $\begin{array}{c}\text { N0 } \\
\text { N (\%) }\end{array}$ & & & \\
\hline \multicolumn{6}{|l|}{$\mathrm{XPD}(\mathrm{A} / \mathrm{C})$} \\
\hline AA & $02(04)$ & $06(24)$ & Reference & Reference & Reference \\
\hline $\mathrm{AC}+\mathrm{CC}$ & $43(96)$ & $19(76)$ & $0.038^{*}$ & 6.789 & $1.254-36.77$ \\
\hline \multicolumn{6}{|l|}{$\mathrm{XPG}(\mathrm{G} / \mathrm{C})$} \\
\hline GG & $23(53)$ & $10(42)$ & Reference & Reference & Reference \\
\hline $\mathrm{GC}+\mathrm{CC}$ & $20(47)$ & $14(58)$ & 0.5 & 0.621 & $0.226-1.704$ \\
\hline Metastasis & $\begin{array}{c}\text { M1 } \\
\text { N (\%) }\end{array}$ & $\begin{array}{c}\text { M0 } \\
\text { N (\%) }\end{array}$ & & & \\
\hline \multicolumn{6}{|l|}{$\mathrm{XPD}(\mathrm{A} / \mathrm{C})$} \\
\hline AA & $01(06)$ & $07(13)$ & Reference & Reference & Reference \\
\hline $\mathrm{AC}+\mathrm{CC}$ & $16(94)$ & $46(87)$ & 0.698 & 2.435 & $0.277-21.36$ \\
\hline \multicolumn{6}{|l|}{ XPG (G/C) } \\
\hline GG & $11(65)$ & $22(44)$ & Reference & Reference & Reference \\
\hline $\mathrm{GC}+\mathrm{CC}$ & $06(35)$ & $28(56)$ & 0.232 & 0.428 & $0.136-1.341$ \\
\hline Tumor stage & $\begin{array}{l}\mathrm{III}+1 \mathrm{~V} \\
\mathrm{~N}(\%)\end{array}$ & $\begin{array}{c}\mathrm{I}+\mathrm{II} \\
\mathrm{N}(\%)\end{array}$ & & & \\
\hline \multicolumn{6}{|l|}{$\mathrm{XPD}(\mathrm{A} / \mathrm{C})$} \\
\hline $\mathrm{AA}$ & $03(06)$ & $05(26)$ & Reference & Reference & Reference \\
\hline $\mathrm{AC}+\mathrm{CC}$ & $48(94)$ & $14(74)$ & $0.049^{*}$ & 5.714 & $1.212-26.93$ \\
\hline \multicolumn{6}{|l|}{ XPG (G/C) } \\
\hline GG & $26(53)$ & 07 (39) & Reference & Reference & Reference \\
\hline $\mathrm{GC}+\mathrm{CC}$ & $23(47)$ & $11(61)$ & 0.451 & 0.562 & $0.187-1.694$ \\
\hline Cell differentiated grade & $\begin{array}{c}>\text { Grade } 1 \\
\text { N ( } \%)\end{array}$ & $\begin{array}{c}\text { Grade } 1 \\
\mathrm{~N}(\%)\end{array}$ & & & \\
\hline \multicolumn{6}{|l|}{$\mathrm{XPD}(\mathrm{A} / \mathrm{C})$} \\
\hline AA & $02(05)$ & $06(20)$ & Reference & Reference & Reference \\
\hline $\mathrm{AC}+\mathrm{CC}$ & $38(95)$ & $24(80)$ & 0.115 & 4.75 & $0.885-25.49$ \\
\hline \multicolumn{6}{|l|}{ XPG (G/C) } \\
\hline GG & $20(55)$ & $13(48)$ & Reference & Reference & Reference \\
\hline $\mathrm{GC}+\mathrm{CC}$ & $16(45)$ & $14(52)$ & 0.743 & 0.742 & $0.272-2.022$ \\
\hline
\end{tabular}

\section{Funding}

The work was supported by Science and Engineering Board (SERB), India.

\section{Ethical Approval}

All procedures performed in studies involving human participants were in accordance with the ethical standards of the institutional and with the 1964 Helsinki declaration and its later amendments or comparable ethical standards.

\section{Conflict of Interest}

None of the author had any conflict of interest

\section{References}

Abbasi R, Ramroth H, Becher H, et al (2009). Laryngeal cancer 
risk associated with smoking and alcohol consumption is modified by genetic polymorphisms in ERCC5, ERCC6 and RAD23B but not by polymorphisms in five other nucleotide excision repair genes. Int $J$ Cancer, 125, 1431-39.

Avci H, Iplik ES, Aydemir L, et al (2018). Are XPD and XPG gene variants related to the mechanism of oral squamous cell carcinoma?. Cell Mol Biol (Noisy-le-grand), 15, 94-99.

Cheng L, Eicher SA, Guo Z, et al (1998). Reduced DNA repair capacity in head and neck cancer patients. Cancer Epidemiol Biomarkers Prev, 7, 465-8.

Cheng L, Sturgis EM, Eicher SA, Spitz MR, Wei Q (2002). Expression of nucleotide excision repair genes and the risk for squamous cell carcinoma of the head and neck. Cancer, 94, 393-97.

Cheng L, Spitz MR, Hong WK, et al (2000). Reduced expression levels ofnucleotide excision repair genes in lung cancer: a case-control analysis. Carcinogenesis, 21, 1527-30.

Du Y, He Y, Mei Z, Qian L, Shi J, Jie Z (2016). Association between genetic polymorphisms in $X P D$ and $X R C C 1$ genes and risks of non-small cell lung cancer in East Chinese Han population. Clin Respir J, 10, 311-7.

Evans E, Fellows J, Coffer A, et al (1997). Open complex formation around a lesion during nucleotide excision repair provides a structure for cleavage by human XPG protein. EMBO J, 16, 625-38.

Ferlay J, Soerjomataram I, Ervik M, et al (2015). Cancer incidence and mortality worldwide: sources, methods and major patterns in GLOBOCAN 2012. Int J Cancer, 5, 136.

Gupta PC, Mehta FS, Pindborg JJ, et al (1992). Primary prevention trial of oral cancer in india: a 10-year follow-up study. J Oral Pathol Med, 21, 433-9.

Goode EL, Ulrich CM, Potter JD (2002). Polymorphisms in DNA repair genes and associations with cancer risk. Cancer Epidemiol Biomarkers Prev, 12, 1513-30.

GuoWF, Lin RX, Huang J, et al (2005). Identification of differentially expressed genes contributing to radio resistance in lung cancer cells using microarray analysis. Radiat Res, 164, 27-35.

He J, Qiu LX, Wang MY, et al (2012). Polymorphisms in the XPG gene and risk of gastric cancer in Chinese populations. Hum Genet, 131, 1235-44.

Kawakami H, Zaanan A, Sinicrope FA (2015). Implications of mismatch repair deficient status on management of early stage colorectal cancer. J Gastrointest Oncol, 6, 676-84.

Lunn RM, Helzlsouer KJ, Parshad R, et al (2000). XPD polymorphisms: effects on DNA repair proficiency. Carcinogenesis, 21, 551-5.

Moreno V, Gemignani F, Landi S, et al (2006). Polymorphisms in genes of nucleotide and base excision repair: risk and prognosis of colorectal cancer. Clin Cancer Res, 12, 2101-8.

MG Closas, Malats N, Real FX, et al (2006). Genetic variation in thenucleotide excision repair pathway and bladder cancer risk. Cancer Epidemiol Biomarkers Prev, 15, 536-42.

O'Donovan A, Davies AA, Moggs JG, West SC, Wood RD (1994). XPG endonuclease makes the 3 ' incision in human DNA nucleotide excision repair. Nature, 371, 432-35.

Pereiraa JDS, Fontesb FL, Medeirosb SRBD, et al (2016). Association of the $X P D$ and $X R C C 3$ gene polymorphisms with oral squamous cell carcinoma in a Northeastern Brazilian population: A pilot study. Arch Oral Biol, 64, 19-23.

Rouissi K, Bahria IB, Bougatef K, et al (2011). The effect of tobacco, XPC,ERCC2 and ERCC5 genetic variants in bladder cancer development. BMC Cancer, 22, 100-1.

Spivak G (2015). Nucleotide excision repair in humans. DNA Repair, 36, 13-8.

Shen M, Berndt SI, Rothman N, et al (2005). Polymorphisms in the DNA nucleotide excision repair genes and lung cancer risk in Xuan Wei, China. Int J Cancer, 116, 768-73.

Sakoda LC, Loomis MM, Doherty JA, et al (2012). Germ line variation in nucleotide excision repair genes and lung cancer risk in smokers. Int J Mol Epidemiol Genet, 3, 1-17.

Sturgis EM, Zheng R, Li L, et al (2000). XPD/ERCC2 polymorphisms and risk of head and neck cancer. Carcinogenesis, 21, 2219-23.

Suguna S, D H Nandal, Kamble S, Bharatha A, Kunkulol R (2014). Genomic dna isolation from human whole blood samples by non enzymatic salting out method. Int J Pharm Pharmaceutical Sci, 6, 198-9.

Sanyal S, Festa F, Sakano S, et al (2004). Polymorphisms in DNA repair and metabolic genes in bladder cancer. Carcinogenesis, 25, 729-34.

Smolarz B, Michalska MM, Samulak D, Romanowicz H, Wójcik L (2019). Polymorphism of DNA repair genes in breast cancer. Oncotarget, 4, 527-35.

Wood RD, Mitchell M, Sgouros J, Lindahl T (2001). Human DNA repair genes. Science, 291, 1284-9.

Yang WG, Zhang SF, Chen JW, et al (2012). SNPs of excision repair cross complementing group 5 and gastric cancer risk in Chinese populations. Asian Pac J Cancer Prev, 13, 6269-72.

Zienolddiny S, Campa D, Lind H, et al (2006). Polymorphisms of DNA repair genes and risk of non-small cell lung cancer. Carcinogenesis, 27, 560-7.

Zhu J, Fu W, Jia W, et al (2018). Association between NER Pathway Gene Polymorphisms and Wilms Tumor Risk. Mol Ther Nucleic Acids, 7, 854-60.

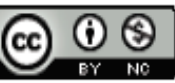

This work is licensed under a Creative Commons AttributionNon Commercial 4.0 International License. 